\title{
Legal linguistics as a mutual arena for cooperation
}

\author{
Recent developments in the field of \\ applied linguistics and law
}

\author{
Jan Engberg
}

\begin{abstract}
This article reports on some of the recent projects and individual works in the field of Legal Linguistics as examples of cooperation between Applied Linguistics and law. The article starts by discussing relevant prototypical concepts of Legal Linguistics. Legal Linguistics scrutinizes interactions between human beings in the framework of legal institutions involving language as a means of communication. Focus is upon creating a mutual arena for cooperation between disciplines, including Applied Linguistics. Legal Linguistics is thus seen as an interdisciplinary approach treating problems of relevance to the law from the point of view of non-legal disciplines. Subsequently, the paper presents four domains of study in Legal Linguistics all characterised by offering opportunities for interdisciplinary cooperation: Forensic linguistic evidence analysis, Drafting and intelligibility, Legal interpretation and meaning, and Discourse studies of law.
\end{abstract}

\section{Introduction: Prototypical concepts and approaches to Legal Linguistics}

In this article selected projects and individual works in the field of Legal Linguistics (LL) will be presented. The intent is to demonstrate ways in which methods and approaches from Applied Linguistics (AL) may be used to investigate challenges and problems from the field of law involving language and communication. The basis is the broad approach to AL propagated by Karlfried Knapp and Gerd Antos. They see AL as "a specific, problem-oriented way of 'doing linguistics' related to the real-life world” (Knapp \& Antos 2011:xi; see also the Introduction to this issue). Regarding LL as a kind of AL therefore means that we start with actual problems from the field of law that may be formulated as problems of language and communication. Furthermore, it means that the idea behind working with these problems is to diagnose and potentially solve the problems by way of insights into language and communication from disciplines connected to AL.

This approach is in accordance with the following definition of LL:

Legal linguistics studies law with linguistic methods and the outcome of the studies can help legal scientists and legal practitioners do and understand their work better through an increased understanding of how language works in general and in legal domains in particular (Salmi-Tolonen 2013:275).

This formulation of the characteristics of LL implies what Sarangi and Candlin (2011:44) have called "a broad view of language and communication including both formal studies of text and discourse 
in a range of modes, grounded ethnographic studies of contexts of use, and more social psychological studies of participants' orientations, identities and interpretive processes." This broadening of the concept of language and thus also of the scope of objects to be studied under the auspices of $\mathrm{AL}$ is relevant as it helps to ensure that the research performed actually treats problems of interest to that part of the real-life world in which the problem occurs (Knapp and Antos 2011: $\mathrm{X}$-xi). It is a consequence of the distribution of different so-called motivational relevancies (i.e., the relevance of an aspect stemming from the motivations for performing the research) for work in AL in professional contexts (Sarangi \& Candlin 2011:34). The relevance of an object of study or of a specific perspective of the object is not given by itself or solely by the interests of the AL scholars. Instead, motivations of the persons interested in or co-performing the AL study are decisive for the epistemological orientation of such studies (Sarangi \& Candlin 2001:368-369). If a legal-linguistic study of, e.g., multilingual communication in court has to achieve relevance for the real-life world studied, relevancies motivating the study and its object and design should be based upon needs, problems and issues recognized as such by the people constituting the part of the real-life world in question (Sarangi \& Candlin 2001:370). And their problems are not easily formulated in strictly linguistic terms, although linguistic categories may help in studying the problems systematically. For instance a study like Mináriková (2006) investigates the distribution of syntactic and semantic characteristics of German provision clauses in statutes. The primarily system-linguistic motivation behind the study may be difficult to align with motivational relevancies of legal experts. On the other hand, a study of the actual intelligibility of differently formulated versions of insurance policies like Becker and Klein (2008) has much higher degree of overlap. Even though it studies formal linguistic aspects of legal texts, it does so in order to help solving the inherently legal problem that in a democratic society the legal institutions (here: insurance companies) cannot neglect the importance of citizens actually understanding the texts constituting the legal rules (cf. Nussbaumer 2004; Nussbaumer 2007).

When cooperating with the discipline of law, it is important to be aware that it sees itself as having tight links to other disciplines like sociology, political science and philosophy, but without being an interdiscipline (Busse 1992: 14; Solan \& Tiersma 2012:1-2). The field of law is thus a field of multiple interests interacting in differing ways, also in the case of LL. In the remainder of this section, concrete approaches to LL will be presented as examples of such different ways. In order to make the differences between the approaches clear, two different, yet intertwined scales will be applied:

- The first scale concerns the degree to which linguistics and law as disciplines are integrated into each other in the interdisciplinary venture of LL. I call this the interdisciplinarity scale (cf. Figure 1). At the left-hand end of the scale, law and linguistics are seen as neatly distinguished and the direction of delivery as being unidirectional towards law, i.e., AL studies seen as mere instruments. The discipline of law is central and distinctly different from AL. This perceived unidirectionality is shown by the arrow pointing from Applied Linguistics to Law. At the righthand end the two disciplines are seen as intertwined. This is shown through the yin-yang-sign, indicating that linguistics and law are seen as two sides of the same coin. The leading question concerning location along the scale is: Does departing from the questions and problems of the law mean that legal studies have a hierarchically higher position than linguistics in LL? Or to what extent may legal questions be seen as having a simultaneous and equally important linguistic side? ${ }^{1}$

1. In most work in English in the field of Legal Linguistics people from the disciplines involved are called linguists and lawyers, respectively. However, as the term lawyer outside this specialised field is frequently used when referring specifically to legal experts working as counsels etc., I use the term legal experts meaning 


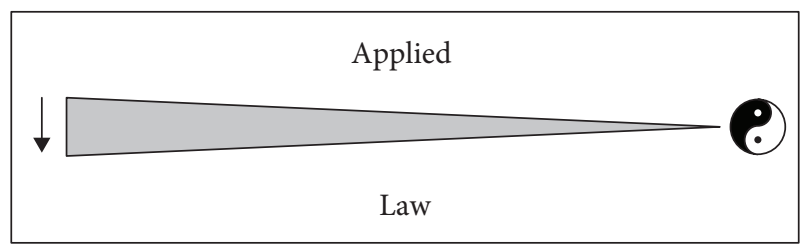

Figure 1. Interdisciplinarity scale

- The second scale concerns the scope of linguistic and communicative approaches with relevance for LL. I call this the language concept scale (cf. Figure 2). At the left-hand end of this scale approaches are found which hold that LL is the application of classical system-oriented linguistic disciplines like syntax and morphology (e.g., looking for specific uses of modal auxiliaries) and should be restricted to these. At the right-hand end of the scale approaches are found which hold that in order to investigate legal problems relevantly (motivational relevance) a broad mind concerning possible concepts of language is necessary, including innovative concepts reaching beyond those normally used in (Applied) Linguistics.

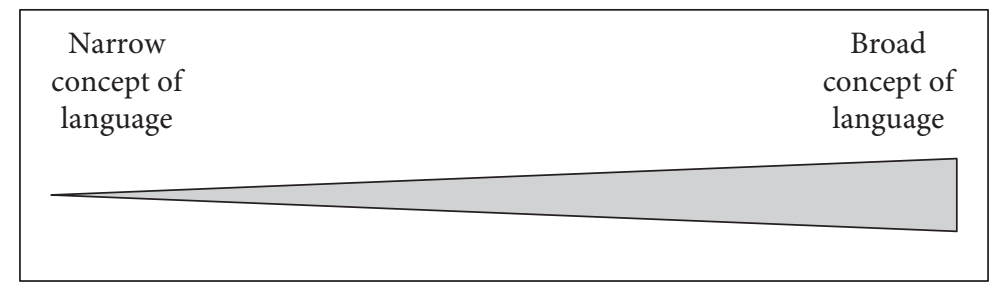

Figure 2. Language concept scale

In the following, these scales will be used to compare and highlight characteristics of central approaches to LL on the basis of their respective positions on the two scales.

As indicated above, on the interdisciplinarity scale we find at the left-hand side approaches putting the discipline of law into the centre and regarding linguistics (and other disciplines alike) as mainly instrumental and thus neatly distinguished from the discipline of law. An example of such an approach we find in Galdia (2009). He sees LL as "an interdisciplinary branch of knowledge" mainly dealing with the questions of "how law is created and how it is applied with linguistic means" (Galdia 2009: 19). His emphasis on these two questions is rooted in his view concerning the most basic aspects of law. In his view, legal argumentation has a central position in the field of legal practice:

The legal discourse which is the overarching structure for the language used in law is by its nature argumentative and law is in fact identical with this specific discourse. ... Once the linguistically relevant essence of the legal argumentation is understood, the rest of the Legal Linguistics ... could be equally well included in footnotes (Galdia 2009:20).

We see a focus upon pragmatic and performative aspects of legal communication (Galdia 2009:73). Linguistic methodologies and concepts are applied to help understand, discuss and solve these problems: "[Legal Linguistics] approaches and describes law as a linguistic phenomenon based on the conviction that language is constitutive for the law" (Galdia 2009: 84-85).

the generic category of scholars with a legal degree and doing professional work in law, i.e., judges, lawyers, administrative staff, etc. 
This position reflects a wide-spread view among legal experts, viz., that linguistics (like many other disciplines like sociology, economy and psychology) is peripheral to the actual centre of the study of law and should be drawn in whenever suitable, although without altering the discipline of law in its core questions and approaches (... equally well included in footnotes). This is most prominently visible when linguistics is used for so-called forensic purposes (cf. below Section 2). E.g., Solan (1998) holds that the role of linguists as expert witnesses in court cases is to function as so-called "semantic tour guides", i.e., to present the facts of a case seen from the point of view of their field of expertise (e.g., semantics), but to leave it to the legal experts to decide the concrete legal questions of the case. Linguists state the (ordinary) meaning of a word on the basis of their expertise; the legal experts decide the legal consequences of the input from the linguists. In more general terms, experts without legal qualifications are regarded as interesting and relevant cooperators, but as outsiders to the kind of discussions and questions that form the actual core of the field.

This is at least to some extent a consequence emerging from the position of Antos, Knapp, Sarangi and Candlin presented above and underlying this article: The motivational relevance of AL studies should be rooted in the problems from outside AL; thus, these others are the ones to decide the playing field. However, it presents AL scholars with a kind of identity problem: Are they mere instrumental experts? In this connection, the position of the respective approach on the interdisciplinarity scale is relevant: the further to the right on the scale, the greater the openness of the approach towards integrating views and insights from outside law proper.

As an example of an approach with a more equal view on the relation between the two disciplines, the book by Mattila (2013) may be mentioned. He defines LL as a discipline which "examines the development, characteristics, and usage of legal language. Studies in this discipline may equally concern vocabulary (notably terminology), syntax (relationships between words), or semantics (the meaning of words) of the language" (Mattila 2013:11). Interesting here is his reliance upon the classical dimensions of linguistic investigation (terminology, syntax, word semantics). It locates him close to the left-hand end of the language concept scale (Figure 2), as opposed to the approach by Galdia above, which departs from the pragmatic functions and thus demonstrates a broader language concept. Mattila regards LL as examining the language of the law, but "in the light of observations made by linguistics" (Mattila 2013:11). LL is to him law subjected to linguistic scrutiny and underlying to some extent the rules of this type of scrutiny.

In the same vein, a recent handbook (Tiersma \& Solan 2012) presents in its introduction the idea that linguistics in a broad sense has acquired a "tremendous foothold ... in the intellectual world" in general over the recent years (Solan \& Tiersma 2012: 1). This is reflected in the central position of post-modernist and social constructivist approaches in many disciplines (linguistic turn). Although social constructivist thinking is still frowned upon in many parts of legal studies, the general insight into the relevance of language as part of the construction of law is growing (Solan \& Tiersma 2012:4). Concerning the language concept scale, the handbook demonstrates a broader language concept than the two approaches presented so far and is thus located towards the righthand end of the language concept scale. They set up six basic directions of study followed in the field of LL as they see it (Solan \& Tiersma 2012:4-9):

1. Studying the specifics of legal language

2. Studying people's interaction with the legal system as well as interactions between people inside the system

3. Studying how laws and statutes are interpreted when applied in practice

4. Studying the consequences of the law being subjected to multilingual settings

5. Studying how language (products) may be legally owned by people 
6. Studying how linguistic evidence may be presented relevantly in court cases

Where the directions 1 and to some extent 3 work with a concept of language akin to what Mattila suggests, the other directions reflect a concept of language as integrated in social interaction.

Further towards the right-hand end of the language concept scale we find approaches like the Danish interdisciplinary research network on LL RELINE, funded since 2011 by the section on Social Sciences of the Danish Council for Independent Research. ${ }^{2}$ The network aims at creating a mutual arena for cooperation between law and disciplines studying communicative events. Thus it is also located close to the right-hand end of the interdisciplinarity scale. The steering committee of the network consists of researchers working in fields of AL (text linguistics, text semantics, translation, discourse analysis, multilingualism, ...), EU law, rhetoric, intellectual property law, human rights law and legal philosophy. LL in this network is seen as an approach which treats problems of relevance to the law from the point of view of one or more non-legal disciplines. A broad concept of language and communication even reaching beyond prototypical AL is seen as necessary in order to be able to cover relevant aspects and problems. The composition of the steering committee demonstrates the intent to integrate the participating disciplines when studying legal problems.

It is not a reasonable goal of a survey article to establish the most adequate position for concrete approaches on the two scales (Figure 1 and 2). The scales are introduced in order to be able to highlight central differences between the approaches, not to evaluate them in any objective sense. For instance, it is probably a question of personal preferences and personal interests whether individual researchers choose to be more or less focused on system linguistics in their approach. But there is also a status question involved here: The broader the language concept and thus the view of what may be the object of LL, the lesser the importance of the disciplines of system linguistics like morphology, syntax and semantics often seen as the core of (applied) linguistics. So AL scholars who engage in the study of language and communication in law under a broad view will tend to have to accept a less central role for such linguistic disciplines and instead enter into interdisciplinary cooperation on a par with researchers from other fields.

Having described some of the prototypical basic approaches to the field of LL today, the remaining part of the article presents concrete and prototypical projects and studies from LL. Modern work on LL may be described in the framework of four domains of study:

- Forensic linguistic evidence analysis: Applying linguistic insights when making legal decisions concerning evidence

- Drafting and intelligibility: Applying linguist insights when formulating legal texts in order for them to become communicatively efficient

- Legal interpretation and meaning: Integrating linguistic insights and consequences of language concepts when finding meaning in legal texts and establishing its legal consequences

- Discourse studies of law: Studying linguistic practices of participants in legal processes

The four domains of work in LL may be positioned on the language concept scale (cf. Figure 3).

As the main idea here is to have a criterion for ordering the different domains, only the language concept scale is used. In the respective descriptions in the following sections, the interdisciplinarity scale is drawn upon, too.

2. <http://jura.ku.dk/reline/>. The ideas underlying the network (cf. Engberg \& Kjær 2011:7) are inspired by Busse (1992). 


\begin{tabular}{|c|c|c|c|}
\hline $\begin{array}{l}\text { Narrow } \\
\text { concept of } \\
\text { language }\end{array}$ & & & $\begin{array}{c}\text { Broad } \\
\text { concept of } \\
\text { language }\end{array}$ \\
\hline $\begin{array}{c}\text { Forensic } \\
\text { linguistic } \\
\text { evidence } \\
\text { analysis }\end{array}$ & $\begin{array}{l}\text { Drafting and } \\
\text { intelligibility }\end{array}$ & $\begin{array}{l}\text { Legal } \\
\text { interpretation } \\
\text { and meaning }\end{array}$ & $\begin{array}{c}\text { Discourse } \\
\text { studies of law }\end{array}$ \\
\hline
\end{tabular}

Figure 3. Complexes of LL presented in this article according to language concept scale

\section{Forensic linguistic evidence analysis}

The area where classical linguistic disciplines are applied most clearly in order to fulfil goals of the legal discipline is probably the field of forensic linguistic evidence analysis. ${ }^{3}$ It is a case of linguistics being put to the service of solving inherently legal problems, i.e., problems of evidence in court cases or similar situations. Concerning the popularity of the field to applied linguists, Shuy (2011) remarks:

One of the odd things about applied linguistics is that it took the field so long to discover that the legal arena is a fertile area in which to apply linguistic knowledge. Even though law is primarily about language, very little of the interaction between linguistics and law occurred until the past quarter century (Shuy 2011:83).

However, there are a number of cases in which the techniques and approaches of AL come in very handy.

Central instances of forensic linguistic evidence analysis are analyses of written and spoken language evidence, including analyses of blackmail letters, suicide notes, wills, hate mail, tape recordings of threat messages, trademarks and possible plagiarising texts (cf. Shuy 2011; Solan \& Tiersma 2012).

Two types of forensic purposes for evidence analysis are especially relevant here: 1) the identification of authors/speakers and 2) the scrutiny of overlaps in meaning and/or form between linguistic products. In the first type of studies (identification of authors/speakers), the idea is to find out who the author or speaker of a text is, regularly in the form of an indication of whether a known person (e.g., a suspect in a criminal case) is author or speaker of a given text or tape recording. This is typically done either through the method of forensic stylistics or through software-based methods of computational linguistics. The basic operation in both cases is to compare texts with

3. Personally I prefer calling this type of application of linguistics to the law forensic linguistics, in accordance with the designation Forensic Science for the "application of all sciences to the law, both civil and criminal", especially oriented towards investigating crime as a service to the Justice System $<\mathrm{http}$ ://www.forensic-science-society.org.uk/home >. I find it relevant from the point of view of a consistent terminology to distinguish between forensic linguistics in this narrow sense and Legal Linguistics as the designation for the broad application of applied linguistics to the field of law (cf. also Kniffka 2007 and Fobbe 2011:15-16). However, as leading scholars in the field (e.g., Coulthard \& Johnson 2010) have suggested to widen the scope of the term forensic linguistics to cover also other types of linguistic study of legal settings like "the role of language in legal dealings with vulnerable witnesses" (Cotterill 2004, vi) or the study of legalese (Shuy 2011:84), I have chosen to clarify that in this section I talk about the specific use of linguistic methods for forensic purposes. 
known authorship to the text under scrutiny. In forensic stylistics, analysers take the (individual) style as a starting point; by applying methods from literary studies they create a profile of the investigated texts highlighting linguistic units that characterise the text (cf., e.g., McMenamin 2002). When based upon computational linguistics, on the other hand, computer software is used in order to detect patterns of importance in a more bottom-up type of process (Chaski 2012:499-502). It relies upon statistics at the character, word and sentence level to detect marked and unmarked elements in the documents compared (Chaski 2012:500). The statistical data are grounded upon base line data concerning regular frequencies across a vast amount of authors and settings. A concrete example of this approach is a case reported by Kredens and Coulthard (2012). In this case, it had to be decided whether a statement by a suspect was partly authored by the police. The analyser established that the statement contained a very high frequency of the word then compared to the frequency in the Corpus of Spoken English from the COBUILD Bank of English, a trait that was shown by other corpus work to be a quantitative characteristic of statements by police officers (Kredens and Coulthard 2012:507). On this basis, the analyser concluded that it was likely that the text had been tampered with. Apart from this analysis of written text applied linguists also carry out analyses of spoken text for the purposes of forensic linguistic evidence analysis, drawing especially upon phonetics and phonology and applying auditory as well as acoustic analyses (Foulkes \& French 2012:562-563).

The second type of purposes for forensic evidence analysis (scrutiny of overlaps in meaning or form) concern situations of plagiarism in academic and copyright/intellectual property contexts (e.g., Butters 2012:463; Woolls 2012:517) and of evaluating whether one trade mark is sufficiently distinct from existing trade marks on phonetic, grammatical, semantic or graphemic grounds (Shuy 2012:454-457). In all of these cases linguistic methods are applied in order to carry out comparisons between language elements at word, sentence and super-sentential (e.g., topic sequences) level. The idea is to assess whether a substantial similarity exists between two texts or two trademarks which may be used as an argument in a plagiarism case (Butters 2012:471). For example, in a concrete case it had to be investigated, whether two articles written by the same authors had a substantial degree of linguistic similarity (as the authors were suspected to publish and be paid for the same content twice; Butters 2012:474-476). This was done by comparing texts and finding overlaps at the level of words, phrases, sentences, etc. So linguistic methodology and the analytical categories are offered as ways of giving a systematic and thus scientifically based description of the central aspects under scrutiny in court cases of this kind, "visualizing" the otherwise tacit knowledge of language among legal experts (Hotta \& Fujita 2012:485).

In the light of the idea of Solan (1998) above of linguists as tour guides and not as deciders of legal questions, making sure to "begin with the lawyers where they are and to not expect lawyers to begin where linguists are" (Shuy 2012:449; see also Shuy 2011:91-96) is of paramount importance. This characteristic locates works in this domain of LL close to the left-hand end of the interdisciplinarity scale (see Figure 1). In a US context, an additional challenge is the general standard for the admissibility of expert evidence called the Daubert standard (Tiersma and Solan 2002). This standard mainly expects methods to comply with four requirements in order to be applied in court:

- $\quad$ to have been tested in similar situations

- $\quad$ to have been subjected to peer review in the respective community

- $\quad$ to have a standard of controlling error rates

- $\quad$ to be generally accepted in the respective community.

The Daubert standard is a challenge to expert witnesses from outside law like experts from AL. But at the same time it actually creates a good opportunity for sound AL analysis to be accepted, as the methods applied are generally accepted for other comparative purposes in AL. 


\section{Legal drafting and intelligibility}

Another relevant set of problems from the field of legal practice concerns the form of legal texts and the impact of form on the efficiency of communication. On the language concept scale we are still close to the left-hand side, as focus is upon the formulation of texts and thus the more formal aspect of the texts (choice of words, complexity of text, use of phrases, ...). However, as meaning and degree of understanding also play a part here, the domain of legal drafting and intelligibility is located to the right of the previous domain on the scale in Figure 3.

In an Anglo-Saxon context in particular, the art of drafting legal texts like statutes and contracts is part of the curriculum at law schools and thus an integral part of what has to be learned in order to qualify as a legal expert. This qualification is, of course, also relevant in a continental European context, but here the tradition is rather that the skill is acquired on the job. Thus it is more of an implicit skill based on tacit knowledge and learnt through a trial-and-error process involving feedback from experienced writers rather than a skill learnt through explicit instructions (although especially ministries tend to have courses in the formulation of statutes etc.).

The legal problem motivating work in this domain of LL is to achieve an efficient and especially an intelligible text. Behind lies the general tenet based upon constitutional rules in (Western) legal systems that the possibility of getting to know a legal rule is a necessary prerequisite for punishing citizens who do not comply with the rules (Simonnæs 2005; cf. also Klein 2004 as well as EichhoffCyrus \& Antos 2008). This is especially relevant in the field of criminal law, based upon the principle from Roman law nulla poena sine lege (no punishment without law). However, it is actually a general standpoint in democratic societies with relevance for legal drafting. As an example the German BGB (the German codification of provisions in the area of civil law) contains the following provision in its $\$ 307$ I on the formulation of standard conditions: Eine unangemessene Benachteiligung kann sich auch daraus ergeben, dass die Bestimmung nicht klar und verständlich ist. ${ }^{4}$

LL projects carried out in recent years with a special focus upon intelligibility in legal drafting tend to fall in two major groups: 1) Those concentrating upon the rhetorical form of the texts and 2) those concentrating upon the knowledge conveyed. The bulk of the work in the first category is placed within the field of plain language (Adler 2012; Asprey 2010; Hülper 2004). One of the leading figures in the so-called Plain Legal Language Movement, Bryan Garner, has the following definition of plain language:

Actually, plain English is typically quite interesting to read. It's robust and direct - the opposite of gaudy, pretentious language. You achieve plain English when you use the simplest, most straightforward way of expressing an idea. You can still choose interesting words. But you'll avoid fancy ones that have everyday replacements meaning precisely the same thing (Garner 2001:xiv).

The main assumption in this quote is that intelligibility problems are rooted in the linguistic and rhetorical choices underlying the textual form, and that different choices may help making the text more intelligible.

Typically, work in this tradition suggests a number of drafting techniques to be followed which lead to the legal text being potentially more accessible and readable. Examples are relatively short sentences, low degree of complexity, avoidance of passive voice, use of bullet points, coherent text structure, etc. (cf., e.g., Adler 2012:76-78). As a concrete example, this approach has had a lot of impact upon actual writing by legal experts in Sweden in particular (Ehrenberg-Sundin 2008). Here, applied linguists have been efficient in setting up linguistically-based general recommendations on

4. "An inadequate disadvantage may result from the fact that the provision is not clear and intelligible." (My translation). 
efficient and accessible legal style issued by the Prime Minister's office, in introducing courses for incoming staff and in creating a general atmosphere in which applied linguists are legitimate participants in the process of drafting legal texts. This is reflected in the fact that applied linguists are working in a division of the Swedish Ministry of Justice on encouraging government officials to use plain language in their drafting and are frequently involved in the formulation of statutes at early stages of the political process. As part of this work, the umbrella authority Språkrådet (The Language Council of Sweden) annually give out an award (Klarspråkskristallen) to an authority that has demonstrated especially good results in the quest for clear administrative language.

Much of the research work on plain legal language in administrative and professional practice is on the attitudes of users of legal texts towards traditional and plain legal texts, respectively, rather than on how much better the reader understands a plain legal text (see, however, Masson \& Waldron 1993, 1994). As early studies in the field of legal intelligibility like (Gunnarsson 1989) and (Wodak, Pfeiffer \& Huk 1983) have shown, higher accessibility or readability is a relevant feature of a text. However, being insufficient for actual intelligibility, this leaves a gap in research.

The other major group of work in this domain of LL intends to fill this gap. They study the knowledge actually conveyed in and through legal texts. The motivation for this type of research is to look behind the surface of the text and the roles in the interaction and get to the actual content, which is seen as the main point in legal communication. Again, these studies can be categorized as falling into two groups: 1) work investigating the content expressed in texts and 2) work (also) empirically investigating the actual uptake of knowledge. Like work in the field of plain language, studies from the first category start from the rhetorical form of the texts. For instance, Lötscher (2008:137-149) suggests principles to be followed at the level of layout, vocabulary, formulations (phrases) and text structure in order to achieve as much transparency as possible, thus rendering the difficult content of the text as accessible as possible. But this type of study focuses in greater detail on the actual content conveyed by the texts studied, thus widening the scope compared to work on plain legal language (see also, e.g., Anesa 2009; Engberg 2008). Works from this category may be seen as a preliminary step towards studies from the second category with a focus upon the knowledge actually constructed by readers on the basis of the text. Such studies focus upon empirically assessing the knowledge that non-experts get out of reading legal texts (e.g., Becker \& Klein 2008; Hansen-Schirra \& Neumann 2004; Hansen, Dirksen, Küchler, Kunz \& Neumann 2006; Janich 2008; Luttermann 2010). This is done by applying different types of psycholinguistic testing of actual understanding.

In sum, the issues of intelligibility of legal texts are a prototypical example of the cooperation of linguists and legal experts. However, also here we see examples of the conflict over the (leading) role of the legal discipline in the cooperation. Lerch (2004), for example, rejects the possibility of including recent linguistic insights on the intelligibility of texts directly into the decision as to whether legal contracts have been formulated in a sufficiently transparent way. In accordance with Solan's dictum of linguistic expert witnesses as tour guides of legal experts, his main argument is that deciding whether the degree of transparency is sufficient is mainly a legal question; external experts like linguists should only be drawn into the decision process if their input allows the legal expert to solve the problem in accordance with legal principles and standards. Recent studies in linguistics tend to reject the possibility of objectively deciding the intelligibility of texts (as they see it as a characteristic of the relation between the text and the receiver rather than a characteristic of the text). In Lerch's view, this position renders the recent linguistic concepts less relevant for the purposes of a legal expert having to decide whether a contract is sufficiently intelligible (Lerch 2004:267; 283). Applied linguists active in the field of LL have to be aware of the fact that making decisions on a basis with as little subjectivity as possible is a central value in the practice of law; this 
position influences the cooperation and locates much work in this domain towards the left-hand end of the interdisciplinarity scale.

\section{Legal interpretation and meaning}

Another central problem of legal experts related to language is the interpretation of texts like contracts, wills and statutes concerning their exact meaning and its legal consequences. Statutory and contractual interpretation is a central aspect of law and legal methodology; legal systems develop sets of possible methods of interpretation to be followed in order to guarantee as sound interpretations as possible. In a German context, e.g., the following methods of interpretation are accepted (Creifelds 2002):

- Grammatical interpretation (= emphasising the wording, i.e., choice of words, syntax, etc., of the texts to be interpreted)

- Systematic interpretation (= emphasising the relation to other provisions in the same legal system)

- Historical interpretation (= emphasising the genesis of the provision)

- Teleological interpretation (= emphasising the societal aim and the intended balancing of interests in society)

The conceptualisation of division of labour seen in the previous two LL domains is also widespread here: Legal experts see themselves as having to solve the interpretive problem; the role of linguists is to support the interpretive solutions reached by the legal expert with linguistic arguments (lefthand side of the interdisciplinarity scale, see Figure 1). An important factor behind this attitude is that interpretation is not seen as only guided by formulations; aspects like for instance the general position of the respective legal system to dimensions of societal life, like the free development of the personality of citizens, play a role, too, as shown in works from comparative law (e.g., FatehMoghadam 2011). However, in the light of such standards of (Western) legal systems as the rule of laws, not of men (Endicott 2000:198), the aspect of the relations between (legal) meaning and the linguistic material expressing it should not be discarded. Thus AL has a role to play here.

An example of a legal problem area where linguistic methodology and insights into the nature of the linguistic system have become relevant is the field of determining the semantic scope of a word or an expression for statutory interpretation. An interesting example is work by the legal expert Clark Cunningham and the linguist Charles Fillmore (Cunningham \& Fillmore 1995). In one case a defendant had used a firearm as payment for drugs. Court discussions on the case focused upon the question whether the expression use a firearm in the relevant statute could be interpreted as covering someone paying for drugs with a gun. Cunningham and Fillmore demonstrate how linguistic semantics can help clarify what the discussions of the judges in this case were actually about. To this end, they apply the linguistic distinction between default interpretations and non-default interpretations of use a firearm. They carry out an analysis of a corpus of texts from British and American newspapers as well as a section of the United States Code establishing the default slots and fillers in the semantic frame underlying the expression, especially concerning the instrumental position. The result is that the everyday default meaning of the debated expression is to use a firearm as a weapon and not as payment. Thus, in linguistic terms a relevant discussion over the interpretation of the expression should have been over whether there were cues in the context inviting a non-default interpretation (Cunningham \& Fillmore 1995: 1179-1180). LL here shows a way to qualify the discussions over meaning by introducing parameters and methods of investigation.

A second relevant area of legal interpretation is in working with texts from multilingual legal systems like the EU, from multilingual states like Canada, Switzerland or Finland, or from international 
commerce. Here LL touches upon practical legal translation, which according to the definition in Section 1 is related to LL, but does not belong to this field. ${ }^{5}$ The special characteristic of multilingual legal systems is that the law is expressed in more than one language and that all language versions are seen as equal sources of law. The traditional methods of legal interpretation mentioned above are not all fully relevant in such contexts. Especially the application of the so-called grammatical approach (traditionally seen as the primary approach in many national European jurisdictions) is problematic, as not one formulation alone, but formulations in more languages together form the basis of the meaning. A multilingual law that does not give priority to one language version over the other necessarily must presuppose the meaning as being some kind of sum of the parallel formulations in the different language versions (cf. Engberg 2012; Solan 2009). The role of the applied linguist in this part of LL is to offer linguistic concepts and methodologies apt for describing this type of meaning. As an example, Engberg (2004:1157-1163) applies a cognitive and constructivist approach to meaning, departing from Relevance Theory to describe emergence and development of legal meaning based upon a number of languages in a case before the European Court of Justice. The case is centred around the problem that the English version of the relevant regulation talks about fish taken from the sea as the object of tax regulations, whereas for instance the German version at the same place talks about the relevant fish as gefangen (= caught). Thus, there is a possible difference in the stage of the fishing process at stake here: fish may be said to be caught (gefangen) already when it is in the nets, whereas the English government argued that it was only taken from the sea when the filled nets were taken out of the water. It is shown in the analysis that the European Court of Justice has been given the pragmatic power to develop a common semantic system for the languages used in EU regulations within the EU legal sphere. They may even overrule the prima facie meaning of a formulation like the English one in this example. The important factor is the basic dynamic character of linguistic meaning, dependent upon the way language users actually use linguistic means. Through such descriptions it is possible to present arguments and reasons for stating that at least a different hierarchy of interpretation methods is necessary in contexts of multilingual legal systems.

The final aspect to be mentioned in this domain of LL studies involves a more abstract set of questions. Discussions in the field of legal argumentation are, among other things, concerned with how the work of interpreting legal experts has to be conceptualised:

- Meaning-as-given-approach: Are legal experts mere interpretation automats which transmit the law into daily life in a mechanical form, following for instance the ideas of the interpreting legal expert as a bouche de la loi and of a so-called Wortlautgrenze of legal interpretation in German law, i.e., limitations for the interpretation stemming from the semantic limits of the words applied in the provision (cf. Klatt 2005)?

- Meaning-as-constructed-approach: Or are legal experts rather subjective and active creators of law in daily life and not strictly speaking limited in their interpretations by the meaning of the wording in a narrow sense, but rather by the intended functions of the provision (cf. Ogorek 2004)?

Behind this lies a disagreement among legal experts concerning the nature of linguistic meaning. Describing the schism creates a possible interface between legal and linguistic expertise. In the first approach (meaning-as-given), linguistic meaning is seen as mainly external to the communicative

5. In Engberg (2013) I argue for the position that legal translation is related to prototypical legal activities like comparative studies of law, but has its own set of purposes leading to differing standards for evaluating translations and comparative law studies, respectively. On these grounds I do not see legal translation as part of LL as defined and described here, although translation is naturally relevant to LL. 
practice and the people involved in it. Meaning is part of the language system, and individual language users draw upon the given meanings when they use the language in communication. Context plays a minor role. The work of the interpreting legal expert may be conceptualised as the quest for the right interpretation hidden in the text to be interpreted. Focus is thus upon dictionary descriptions of words.

In the second approach (meaning-as-constructed), linguistic meaning is seen as mainly internal to and dependent upon communicative practice and interaction among the people involved in it. Context plays a major role. Words mean what users apply them and understand them to mean in specific contexts. The work of an interpreting legal expert consists in constructing (not merely finding) a consistent, well-argued and systematically suitable meaning of the formulations found in the statute or contract under scrutiny. This approach is closely related to Wittgenstein's idea in Philosophische Untersuchungen of the use of words in language games as the decisive factor of the meaning of words and of the role of the individual in the (re-)creation of meaning (Wittgenstein 1984). In linguistic terms it is a question of the degree to which context has to be taken into account when interpreting legal texts. In works from the field of LL this has been treated as a distinction between textualists (meaning-as-given) and intentionalists (meaning-as-constructed) (Solan 2005a, 2005b) or as a distinction between a strong (meaning-as-given) and a weak (meaning-as-constructed) language theory (Christensen \& Kudlich 2002; Christensen \& Sokolowski 2002; Engberg 2004). Interestingly from the point of view of the interdisciplinarity scale, the clarification of the background assumptions of the two different positions has also in some cases created a space for applied linguists to acquire a more central role as described so far. For instance, the founder of the so-called Strukturierende Rechtslehre, the German law professor Friedrich Müller, has convened an interdisciplinary group of legal experts and linguists developing linguistic models of legal communication as well as legal models of statutory interpretation. These models are based on discussions in which (linguistic) insights into the functioning of linguistic meaning in communicative practice interact with conditions from legal philosophy (cf., e.g., Müller 1989; Müller \& Wimmer 2001). The work by Felder (2003) is a good example: The argumentation of German courts at different hierarchical levels on a case concerning sit-down blockades as a means of demonstration in Germany is studied. The courts reach different conclusions, respectively, and the study applies the analytical tool of linguistically based knowledge frames to show the differences in position between the courts as well as the way these positions are reflected in the media at the time. Felder shows how the process of developing argumentation typical of court practice is in accordance with a knowledge-based and dynamic view on linguistic meaning. The approaches interact; legal approach and AL approach supplement each other in presenting a rich picture of the legal process.

\section{Discourse studies of law}

The type of AL studies with the widest concept of language and therefore the type located closest to the right-hand end of the language concept scale, is the analysis of spoken and written discourse in legal settings. The motivation for this type of research is regularly to reveal the distribution of power between the participants in the legal process, focusing for instance upon the disempowered position of foreign-language defendants that cannot follow the proceedings in court as they lack relevant language skills. Studies are often carried out using types of (critical) discourse analysis and conversational analysis, focusing upon the interaction between, e.g., prosecutor, defence attorney, judge and defendant. Recent examples of this type of work are Cotterill (2003), Harris (2011), Heffer (2005) and Stygall (2012). Their motivation is regularly to describe how the situation in court may be improved for ordinary citizens and to reveal the mechanisms underlying the behaviour of legal experts. In the remainder of this section, examples of this kind of study are presented. 
The use and role of interpreters in formal and informal legal settings (police interrogations, informal negotiations, court proceedings, etc.) is a specific legal communicative situation investigated in this domain of studies. As is the case with legal translation, practical oral legal interpretation is not regarded as a case of LL here (cf. Section 4 and note 5). However, as oral legal interpretation solves a problem of legal practice (viz., to carry out legal proceedings in a legally appropriate manner despite the participants not sharing the same language), analyses of the way it is performed and how it influences interrogations and proceedings certainly belong to LL. Concrete studies will not be presented in detail here. ${ }^{6}$ Yet studies have shown that the position of many legal practitioners (seeing the interpreter as an invisible and non-interfering mediator) does not coincide with what takes place in actual practice (e.g., Berk-Seligson 2002; Hale 2004; Jacobsen 2012; Kadric 2001; Pöllabauer 2005). However, the visible and active interpreter supports the process of communication in many cases, thus actually helping the legal practitioners and especially the judge to reach their communicative goals. Therefore, it is necessary for legal practitioners involved in multilingual settings to know more about how to cooperate with legal interpreters. Applied linguists have an important role to play in this.

Another legal discourse area treated in this domain of LL is the field of arbitration and mediation, i.e. of alternative ways of settling disputes that would traditionally be settled in court by a judge following the official rules. This type of studies is related to the previously mentioned type as they are interested in describing ways of settling disputes without the high degree of formality and formalistic power laid down in the court system. Examples of early work of this type is Candlin and Maley (1997) on mediation and Nothdurft (1995) on arbitration in different settings.

Two major international projects based at City University of Hong Kong serve as examples in order to demonstrate the wider language concept underlying discourse oriented studies of the type described above. Between 1999 and 2011 the projects investigated international commercial arbitration in a number of different national settings. The projects may be seen as two interlocking phases of investigation, one with a more traditional language concept and one following a broader, more discourse-oriented language concept. In the first phase, written legal texts on and from international commercial arbitration (e.g., statutes, arbitration agreements, arbitration awards) from a considerable number of countries and jurisdictions were investigated, mainly with the analytical instruments of genre analysis. ${ }^{7}$ Interest was in investigating formal differences between legal texts with similar functions, but dependent upon different legal systems and legal settings. The research interest was mainly textual (to investigate differences in textual products from different contextual settings, or more concretely to see to what extent the same legal genres differ linguistically across jurisdictions); and the object of study was the professional written practice of legal experts in this field. In the follow-up project, on the other hand, the concept of language underlying the project and governing what was relevant input to the analysis was widened considerably. Data in the second project were the written texts, as in the first project, but also, and preferably, the observation of actual arbitration cases and interviews with professional practitioners about their practice. The central hypothesis behind the second project was that a kind of colonisation of the arbitration process is taking place as a consequence of the fact that international commercial arbitration is nowadays to a large extent performed by legal experts. In the project, intertextual and interdiscursive relations were central objects of analysis; i.e., analyses investigated the relation between texts and formulations used in arbitration discourse and in other discourse orders. It was shown that recent arbitration discourse is

6. Cf. Berk-Seligson (2012) for an overview over studies in the field.

7. Cf. Bhatia, Candlin and Engberg (2008) for an overview of this project. 
characterised by discursive features stemming from court discourse. The original character of informality and equality of arbitration and mediation tends to disappear (Bhatia, Candlin \& Gotti 2012).

What is visible when comparing the two projects is a shift in the object of study: From a main interest in the strictly linguistic performance in the first project to a view in the second project of linguistic products mainly as avenues to investigating the (societal) forces driving developments of practices. This shift of object and interest makes the motivational relevance behind this type of AL studies differ from those presented in the first three domains. There the main idea is to depart from a problem recognised by legal experts as part of their core activity. In this fourth domain of studies, however, the motivation is rather to reveal and criticise developments and behaviour in the legal field, in the service of society, as it were. Thus, the motivation is more external to the central interests and problems of the legal profession. This does not mean that the results of this type of work are not relevant to legal experts. As an example, the discursively and ethnographically oriented work by Adrian (2012) on mediation as a (legal) practice in Denmark is carried out by a legal expert and for the purposes of finding out whether the practice of legal experts lives up to legislative intentions. But as a tendency, this type of work will be more critical in its approach than is the case with work belonging to the other categories presented here, maybe with the exception of work in the field of plain legal language. Interest of AL and the legal experts are less intertwined here. Thus, work in this domain is located more to the left-hand side of the interdisciplinarity scale.

\section{Concluding remarks}

As will have become clear throughout this article, AL and law have a mixed relationship. They share interest in a common object (language in use in a professional setting) and they share interest in achieving similar goals (conveying information and argumentation in an efficient way). However, a kind of subdued struggle is continually going on between the disciplines concerning who has the ultimate power to define the object (as expressed in the interdisciplinarity scale, see Figure 1):

- Is it the discipline of law alone, because its members know and "possess" the type of communicative and discursive problems to be treated through studying language in legal settings?

- Or are AL scholars to be seen as equal participants in the definition of the problems of legal experts, because they have an elaborate knowledge of the functioning of language in its different conceptualisations and thus can contribute with indispensable insights?

This struggle is probably unsolvable. But the field of LL has the potential of functioning as a forum for interdisciplinary cooperation between AL scholars and legal experts leaving the struggle behind. A number of scholarly professional associations have emerged recently, in which applied linguists and legal experts come together in order to investigate legal communication and its professional problems. ${ }^{8}$ Thus the future looks bright, probably as long as participants manage to focus the conversation between the disciplines on problems and their solution rather than on the definition of objects.

\section{References}

Adler, M. 2012. The plain language movement. In The Oxford Handbook of Language and Law, P. Tiersma \& L. Solan (eds), 67-85. Oxford: OUP. DOI: 10.1093/oxfordhb/9780199572120.013.0006

Adrian, L. 2012. Mellem retssag og rundbordssamtale. Retsmoegling i teori og praksis. København: Jurist- og Økonomforbundets Forlag.

8. Cf. also Schweizer (2007) for arguments from the point of view of a legal expert for integrating legal theory, language criticism and (applied) linguistics. 
Anesa, P. 2009. "Now you are getting into the law": The mediation of specialised language in a jury trial. Fachsprache. International Journal of LSP 31(1-2): 64-82.

Asprey, M. 2010. Plain Language for Lawyers, 4th edn. Annandale NSW: The Federation Press.

Becker, A. \& Klein, W. 2008. Recht verstehen. Wie Laien, Juristen und Versicherungsagenten die 'Riester-Rente' interpretieren. Berlin: Akademie Verlag.

Berk-Seligson, S. 2002. The Bilingual Courtroom: Court Interpreters in the Judicial Process. Chicago IL: University of Chicago Press.

Berk-Seligson, S. 2012. Linguistic issues in courtroom interpretation. In Oxford Handbook of Language and Law, L.M. Solan \& P.M. Tiersma (eds), 421-434. Oxford: OUP.

Bhatia, V.K., Candlin, C.N. \& Engberg, J. 2008. Concepts, contexts and procedures in arbitration discourse. In Legal Discourse across Cultures and Systems, V.K. Bhatia, C.N. Candlin \& J. Engberg (eds), 3-31. Hong Kong: Hong Kong University Press. DOI: 10.5790/hongkong/9789622098510.001.0001

Bhatia, V.K., Candlin, C.N. \& Gotti, M. 2012. Contested identities in international arbitration Practice. In Discourse and Practice in International Commercial Arbitration. Issues, Challenges and Prospects, V.K. Bhatia, C.N. Candlin \& M. Gotti (eds), 301-318. Farnham: Ashgate.

Busse, D. 1992. Recht als Text. Tübingen: Niemeyer. DOI: 10.1515/9783111377063

Butters, R.R. 2012. Language and copyright. In The Oxford Handbook of Language and Law, P. Tiersma \& L. Solan (eds), 463-477. Oxford: OUP. DOI: 10.1093/oxfordhb/9780199572120.013.0034

Candlin, C.N. \& Maley, Y. 1997. Intertextuality and interdiscursivity in the discourse of alternative dispute resolution. In The Construction of Professional Discourse, B.-L. Gunnarsson, P. Linell \& B. Nordberg (eds), 201-222. London: Longman.

Chaski, C.E. 2012. Author identification in the forensic setting. In The Oxford Handbook of Language and Law, P. Tiersma \& L. Solan (eds), 489-503. Oxford: OUP. DOI: 10.1093/oxfordhb/9780199572120.013.0036

Christensen, R. \& Kudlich, H. 2002. Die Auslegungslehre als implizite Sprachtheorie der Juristen. Archiv für Rechts- und Sozialphilosophie 88: 230-246.

Christensen, R. \& Sokolowski, M. 2002. Wie normativ ist Sprache? Der Richter zwischen Sprechautomat und Sprachgesetzgeber. In Sprache und Recht, U. Haß-Zumkehr (ed.), 64-79. Berlin: De Gruyter.

Cotterill, J. 2003. Language and Power in Court: A Linguistic Analysis of the O. J. Simpson Trial. Basingstoke: Palgrave Macmillan. DOI: 10.1057/9780230006010

Cotterill, J. 2004. Language in Court. Basingstoke: Palgrave Macmillan.

Coulthard, M. \& Johnson, A. (eds). 2010. The Routledge Handbook of Forensic Linguistics. London: Routledge. Creifelds, C. 2002. Rechtswörterbuch, 17th edn. München: C. H. Beck.

Cunningham, C.D. \& Fillmore, C.J. 1995. Linguistic analyses of judicial decisionmaking. Using common sense: A linguistic perspective on judicial interpretations of 'Use a firearm'. Washington University Law Quarterly 73(3): 1159-1214.

Ehrenberg-Sundin, B. 2008. The Swedish approach to clear legislation and clear official texts. In Obscurity and Clarity in the Law: Prospects and Challenges, A. Wagner \& S. Cacciaguidi-Fahy (eds), 165-180. Farnham: Ashgate.

Eichhoff-Cyrus, K.M. \& Antos, G. (eds). 2008. Verständlichkeit als Bürgerrecht? Die Rechts- und Verwaltungssprache in der öffentlichen Diskussion [Thema Deutsch 9]. Mannheim: Dudenverlag.

Endicott, T. 2000. Vagueness in Law. Oxford: OUP. DOI: 10.1093/acprof:oso/9780198268406.001.0001

Engberg, J. 2004. Statutory texts as instances of language(s) - Consequences and limitations on interpretation. Brooklyn Journal of International Law 29(3): 1135-1166.

Engberg, J. 2008. Begriffsdynamik im Recht - Monitoring eines möglichen Verständlichkeitsproblems. In Profession \& Kommunikation [Forum Angewandte Linguistik 49], H. Diekmannshenke \& S. Niemeier (eds), 75-95. Frankfurt: Peter Lang.

Engberg, J. 2012. Word meaning and the problem of a globalized legal order. In Oxford Handbook of Language and Law, L.M. Solan \& P.M. Tiersma (eds), 175-186. Oxford: OUP. DOI: 10.1093/oxford$\mathrm{hb} / 9780199572120.013 .0013$ 
Engberg, J. 2013. Comparative law for translation: The key to successful mediation between legal systems. In Legal Translation in Context: Professional Issues and Prospects, A. Borja Albi \& F. Prieto Ramos (eds), 9-25. Bern: Peter Lang.

Engberg, J. \& Kjær, A.L. 2011. Approaches to language and the law - Some introductory notes. Hermes 46: $7-10$.

Fateh-Moghadam, B. 2011. Operativer Funktionalismus in der Strafrechtsvergleichung. In Strafrechtsvergleichung als Problem und Lösung, S. Beck, C. Burchard \& B. Fateh-Moghadam (eds), 4363. Baden-Baden: Nomos. DOI: 10.5771/9783845228419

Felder, E. 2003. Juristische Textarbeit im Spiegel der Öffentlichkeit [Studia Linguistica Germanica 70]. Berlin: Walter de Gruyter. DOI: 10.1515/9783110894721

Fobbe, E. 2011. Forensische Linguistik: Eine Einführung. Tübingen: Narr.

Foulkes, P. \& French, P. 2012. Forensic speaker comparison: A linguistic-acoustic perspective. In The Oxford Handbook of Language and Law, P. Tiersma \& L. Solan (eds), 557-572. Oxford: OUP. DOI: 10.1093/ oxfordhb/9780199572120.013.0041

Galdia, M. 2009. Legal Linguistics. Frankfurt: Peter Lang.

Garner, B.A. 2001. Legal Writing in Plain English: A Text with Exercises. Chicago IL: Chicago University Press. DOI: $10.7208 /$ chicago/9780226284200.001.0001

Gunnarsson, B.-L. 1989. Text comprehensibility and the writing process. The case of laws and lawmaking. Written Communication 6(1): 86-107. DOI: 10.1177/0741088389006001006

Hale, S. 2004. The Discourse of Court Interpreting: Discourse Practices of the Law, the Witness and the Interpreter. Amsterdam: John Benjamins. DOI: 10.1075/btl.52

Hansen-Schirra, S. \& Neumann, S. 2004. Linguistische Verständlichmachung in der juristischen Realität. In Recht Verstehen. Verständlichkeit, Missverständlichkeit und Unverständlichkeit von Recht [Die Sprache des Rechts 1], K.D. Lerch (ed.), 167-184. Berlin: De Gruyter.

Hansen, S., Dirksen, R., Küchler, M., Kunz, K. \& Neumann, S. 2006. Comprehensible legal texts - Utopia or a question of wording? On processing rephrased German court decisions. Hermes 36: 15-40.

Harris, S. 2011. Interrogation and evidence: Questioning sequences in courtroom discourse and police interviews. In Handbook of Communication in Organisations and Professions, C. Candlin \& S. Sarangi (eds). 277-298. Berlin: De Gruyter. DOI: 10.1515/9783110214222.277

Heffer, C. 2005. The Language of Jury Trial: A Corpus-Aided Analysis of Legal-Lay Discourse. Houndsmills: Palgrave Macmillan.

Hotta, S. \& Fujita, M. 2012. The psycholinguistic basis of distinctiveness in trademark law. In The Oxford Handbook of Language and Law, P. Tiersma \& L. Solan (eds), 478-486. Oxford: OUP. DOI: 10.1093/ oxfordhb/9780199572120.013.0035

Hülper, M. 2004. Die englische Rechtssprache - Verständlichkeit für Laien und Sprachunkundige. Münster: LIT. Jacobsen, B. 2012. The significance of interpreting modes for question-answer dialogues in court interpreting. Interpreting 14(2): 217-241. DOI: 10.1075/intp.14.2.05jac

Janich, N. 2008. Universitäre Kommunikation im Spannungsfeld von Rechtssicherheit und Zielgruppenadäquatheit. Fachsprache 30(1-2): 30-42.

Kadric, M. 2001. Dolmetschen bei Gericht: Erwartungen, Anforderungen, Kompetenzen. Wien: WUV.

Klatt, M. 2005. Die Wortlautgrenze. In Recht verhandeln. Argumentieren, Begründen und Entscheiden im Diskurs des Rechts [Die Sprache des Rechts 2], K.D. Lerch (ed.), 343-368. Berlin: De Gruyter. DOI: $10.1515 / 9783110927313.343$

Klein, W. 2004. Ein Gemeinwesen, in dem das Volk herrscht, darf nicht von Gesetzen beherrscht werden, die das Volk nicht versteht. In Recht Verstehen. Verständlichkeit, Missverständlichkeit und Unverständlichkeit von Recht [Die Sprache des Rechts 1], K.D. Lerch (ed.), 197-203. Berlin: De Gruyter.

Knapp, K. \& Antos, G. 2011. Introduction to the handbook series Linguistics for problem solving. In Handbook of Communication in Organisations and Professions, C.N. Candlin \& S. Sarangi (eds), v-xv. Berlin: De Gruyter. DOI: 10.1515/9783110214222.v

Kniffka, H. 2007. Working in Language and Law. A German Perspective. Houndmills: Palgrave Macmillan. DOI: $10.1057 / 9780230590045$ 
Kredens, K. \& Coulthard, M. 2012. Corpus linguistics in authorship identification. In The Oxford Handbook of Language and Law, P. Tiersma \& L. Solan (eds), 504-516. Oxford: OUP. DOI: 10.1093/oxford$\mathrm{hb} / 9780199572120.013 .0037$

Lerch, K.D. 2004. Verständlichkeit als Pflicht? Zur Intransparenz des Transparenzgebotes. In Recht Verstehen. Verständlichkeit, Missverständlichkeit und Unverständlichkeit von Recht [Die Sprache des Rechts 1], K.D. Lerch (ed.), 239-283. Berlin: De Gruyter.

Luttermann, K. 2010. Verständliche Semantik in schriftlichen Kommunikationsformen. Fachsprache. International Journal of LSP 32(3-4): 145-162.

Lötscher, A. 2008. Conceptual and textual structure in legislative texts. In Obscurity and Clarity in the Law: Prospects and Challenges, A. Wagner \& S. Cacciaguidi-Fahy (eds), 129-150. Farnham: Ashgate.

Masson, M. \& Waldron, M.A. 1994. Comprehension of legal contracts by non-experts: Effectiveness of plain language redrafting. Applied Cognitive Psychology 8: 67-85. DOI: 10.1002/acp.2350080107

Masson, M. \& Waldron, M.A. 1993. Plain language contracts and reader comprehension. In Proceedings. Just Language Conference 1992, 110-125. Vancouver: Plain Language Institute.

Mattila, H.E.S. 2013. Comparative Legal Linguistics, 2nd edn. Farnham: Ashgate.

McMenamin, G. 2002. Forensic Linguistics: Advances in Forensic Stylistics. Boca Raton FL: CRC Press. DOI: $10.1201 / 9781420041170$

Mináriková, M. 2006. Der deutschsprachige Rechtssatz: Untersuchungen zu seinen syntaktisch-semantischen Charakteristika im deutschen Strafgesetzbuch. Ein Beitrag zur deutschen Fachsprache als Sprachenbrücke im vereinten Europa. Hamburg: Verlag Dr. Kovac.

Müller, F. 1989. Untersuchungen zur Rechtslinguistik. Berlin: Duncker \& Humblot.

Müller, F. \& Wimmer, R. (eds). 2001. Neue Studien zur Rechtslinguistik. Berlin: Duncker \& Humblot.

Nothdurft, W. (ed.). 1995. Streit schlichten. Gesprächsanalytische Untersuchungen zu institutionellen Formen konsensueller Konfliktregelung [Schriften des Instituts für deutsche Sprache 5.1]. Berlin: De Gruyter. DOI: $10.1515 / 9783110877465$

Nussbaumer, M. 2007. Gesetze verständlicher machen - dass ich nicht lache! In Denken wie ein Philosoph und schreiben wie ein Bauer. Sprache, mit der ein Staat zu machen ist, A. Lötscher \& M. Nussbaumer (eds), 43-66. Zürich: Schulthess.

Nussbaumer, M. 2004. Von Schwärmern und Skeptikern und ein Versuch, Realist zu sein. Bilanz und Entwurf des Sprachspiels von unverständlichen Gesetz. In Recht Verstehen. Verständlichkeit, Missverständlichkeit und Unverständlichkeit von Recht [Die Sprache des Rechts 1], K.D. Lerch (ed.), 285-295. Berlin: De Gruyter.

Ogorek, R. 2004. 'Ich kenne das Reglement nicht, habe es aber immer befolgt!' Metatheoretische Anmerkungen zur Verständnisdebatte. In Recht Verstehen. Verständlichkeit, Missverständlichkeit und Unverständlichkeit von Recht[Die Sprache des Rechts, 1], K.D. Lerch (ed.), 297-305. Berlin/New York: de Gruyter.

Pöllabauer, S. 2005. "I Don't Understand Your English, Miss": Dolmetschen bei Asylanhörungen [Translationswissenschaft 2]. Tübingen: Narr.

Salmi-Tolonen, T. 2013. Legal linguistics as a line of study and an academic discipline. In Language in the Negotiation of Justice. Contexts, Issues and Applications, C. Williams \& G. Tessuto (eds), 259-278. Farnham: Ashgate.

Sarangi, S. \& Candlin, C.N. 2001. 'Motivational Relevancies': Some methodological reflections on social theoretical and sociolinguistic practice. In Sociolinguistics and Social Theory, N. Coupland, S. Sarangi \& C.N. Candlin (eds), 350-388. Harlow: Pearson.

Sarangi, S. \& Candlin, C.N. 2011. Professional and organisational practice: A discourse/communication perspective. In Handbook of Communication in Professions and Organizations, C.N. Candlin \& S. Sarangi (eds), 3-59. Berlin: Mouton de Gruyter. DOI: 10.1515/9783110214222

Schweizer, R.J. 2007. Die Sprache als Grundlage des Rechts. In Denken wie ein Philosoph und schreiben wie ein Bauer. Sprache, mit der ein Staat zu machen ist, A. Lötscher \& M. Nussbaumer (eds), 13-33. Zürich: Schulthess. 
Shuy, R.W. 2011. Applied linguistics in the legal arena. In Handbook of Communication in Organisations and Professions, C.N. Candlin \& S. Sarangi (eds), 83-102. Berlin: De Gruyter.

Shuy, R.W. 2012. Using Linguistics in trademark cases. In The Oxford Handbook of Language and Law, P. Tiersma \& L. Solan (eds), 450-462. Oxford: OUP.

Simonnæs, I. 2005. Verstehensprobleme bei Fachtexten [Nordeuropäische Beiträge aus den Human- und Gesellschaftswissenschaften 26]. Frankfurt: Peter Lang.

Solan, L.M. 2009. The interpretation of multilingual statutes by the European Court of Justice. Brooklyn Journal of International Law 34(2): 277-301.

Solan, L.M. 1998. Linguistic experts as semantic tour guides. Forensic Linguistics 5(2): 87-106.

Solan, L.M. 2005a. The new textualists' new text. Loyola Law Review 38(5): 2027-2062.

Solan, L.M. 2005b. Private language, public laws: The central role of legislative intent in statutory interpretation. Georgetown Law Journal 93(2): 427-486.

Solan, L.M. \& Tiersma, P.M. 2012. Introduction. In The Oxford Handbook of Language and Law, P. Tiersma \& L. Solan (eds), 1-9. Oxford: OUP. DOI: 10.1093/oxfordhb/9780199572120.001.0001

Stygall, G. 2012. Discourse in the US courtroom. In The Oxford Handbook of Language and Law, P. Tiersma \& L. Solan (eds), 369-380. Oxford: OUP. DOI: 10.1093/oxfordhb/9780199572120.013.0027

Tiersma, P. \& Solan, L. 2012. The Oxford Handbook of Language and Law. Oxford: OUP. DOI: 10.1093/oxfordhb/9780199572120.001.0001

Tiersma, P.M. \& Solan, L.M. 2002. The linguist on the witness stand: Forensic linguistics in American courts. Language 78: 229-230. DOI: 10.1353/lan.2002.0135

Wittgenstein, L. 1984. Tractatus logico-philosophicus. Tagebücher 1914-1916. Philosophische Untersuchungen. Werkausgabe, Bd. 1. Frankfurt: Suhrkamp.

Wodak, R., Pfeiffer, O. \& Huk, E. 1983. Verständlichkeit und Gesetzestext. Eine textlinguistische Studie. In Bürgernahe Gesetzestexte in Nierderösterreich. Ein interdisziplinäres Projekt. Dokumentation, Amt der Niederösterreichischen (Landesregierung) \& E. Huk (eds). Wien: Amt der Niederösterreichischen Landesregierung.

Woolls, D. 2012. Detecting plagiarism. In The Oxford Handbook of Language and Law, P. Tiersma \& L. Solan (eds), 517-529. Oxford: OUP. DOI: 10.1093/oxfordhb/9780199572120.013.0038

\section{Author's address}

Jan Engberg

Aarhus University

Jens Chr. Skousvej 4

DK-8210 Aarhus V

je@asb.dk 